\title{
Annual Trends in Ultrasonography-Guided 14-Gauge Core Needle Biopsy for Breast Lesions
}

\author{
Inha Jung, $\mathrm{MD}^{1}$, Kyunghwa Han, $\mathrm{PhD}^{2}$, Min Jung Kim, MD, $\mathrm{PhD}^{1}$, Hee Jung Moon, MD, PhD ${ }^{1}$,
} Jung Hyun Yoon, MD, PhD ${ }^{1}$, Vivian Youngjean Park, MD, PhD ${ }^{1}$, Eun-Kyung Kim, MD, PhD ${ }^{1}$

${ }^{1}$ Department of Radiology and Research Institute of Radiological Science, Severance Hospital, Yonsei University College of Medicine, Seoul, Korea; ${ }^{2}$ Department of Radiology and Research Institute of Radiological Science, Yonsei Biomedical Research Institute, Seoul, Korea

Objective: To examine time trends in ultrasonography (US)-guided 14-gauge core needle biopsy (CNB) for breast lesions based on the lesion size, Breast Imaging-Reporting and Data System (BI-RADS) category, and pathologic findings.

Materials and Methods: We retrospectively reviewed consecutive US-guided 14-gauge CNBs performed from January 2005 to December 2016 at our institution. A total of 22,297 breast lesions were included. The total number of biopsies, tumor size ( $\leq 10 \mathrm{~mm}$ to $>40 \mathrm{~mm}$ ), BI-RADS category (1 to 5), and pathologic findings (benign, high risk, ductal carcinoma in situ [DCIS], invasive cancer) were examined annually, and the malignancy rate was analyzed based on the BI-RADS category.

Results: Both the total number of US scans and US-guided CNBs increased while the proportion of US-guided CNBs to the total number of US scans decreased significantly. The number of biopsies classified based on the tumor size, BI-RADS category, and pathologic findings all increased over time, except for BI-RADS categories 1 or 2 and category 3 (odds ratio [0R] $=0.951$ per year, 95\% confidence interval [CI]: 0.902, 1.002 and odds ratio $=0.979,95 \%$ CI: $0.970,0.988$, respectively). Both the unadjusted and adjusted total malignancy rates and the DCIS rate increased significantly over time. BI-RADS categories 4a, $4 \mathrm{~b}$, and $4 \mathrm{c}$ showed a significant increasing trend in the total malignancy rate and DCIS rate.

Conclusion: The malignancy rate in the results of US-guided 14-gauge CNB for breast lesions increased as the total number of biopsies increased from 2005 to 2016. This trend persisted after adjusting for the BI-RADS category.

Keywords: Breast cancer; Ultrasonography; Image-guided biopsy; Trends

\section{INTRODUCTION}

Image-guided core needle biopsy (CNB) is considered the gold standard diagnostic modality for breast lesions and a reliable alternative to surgical excisional biopsy (1-5). Many studies have reported that percutaneous ultrasonography (US)-guided CNB has several advantages over stereotactic or surgical biopsy. It is less invasive, less expensive, and

Received September 16, 2019; accepted after revision December 16, 2019.

Corresponding author: Eun-Kyung Kim, MD, PhD, Department of Radiology and Research Institute of Radiological Science, Severance Hospital, Yonsei University College of Medicine, 50-1 Yonsei-ro, Seodaemun-gu, Seoul 03722, Korea.

- Tel: (822) 2228-7400 - Fax: (822) 393-3035

- E-mail: ekkim@yuhs.ac

This is an Open Access article distributed under the terms of the Creative Commons Attribution Non-Commercial License (https://creativecommons.org/licenses/by-nc/4.0) which permits unrestricted non-commercial use, distribution, and reproduction in any medium, provided the original work is properly cited. faster to perform; further, it can be performed in real time while still allowing accurate assessments without exposure to ionizing radiation $(4,6,7)$. Many studies also have proven that US-guided 14-gauge CNB provides optimal diagnostic information for breast lesions with low falsenegative rates and accuracy comparable to that of surgical biopsy $(3,5,6,8)$. Furthermore, the number of breast imaging studies utilizing screening mammography and US has increased, resulting in increased lesion detection and biopsy recommendation. Therefore, US-guided CNB has been increasingly performed since its introduction. However, its subsequent utilization has led to concerns about an unnecessary increase in the number of biopsies associated with benign biopsy results.

In the United States, more than 1 million breast biopsies are performed annually, and approximately $80 \%$ of cases are benign $(9,10)$. However, data are limited on which lesions have been increasingly biopsied over time. USguided CNB would be cost-ineffective and would be of 
clinical insignificance if the increasing number of biopsies does not lead to increased breast cancer detection. With the number of total biopsies increasing over time, the malignancy rate in the results of CNB must be kept constant or increase in order to ensure that unnecessary biopsies are not performed.

The purpose of this study was to examine annual trends in breast lesion characteristics (e.g., lesion size, the Breast Imaging-Reporting and Data System [BI-RADS] category established by the American College of Radiology, and pathologic findings) and the malignancy rate based on a large series of US-guided CNB over a 12-year study period.

\section{MATERIALS AND METHODS}

\section{Study Population}

This study was conducted with the approval of the Institutional Review Board (4-2019-0636), and the requirement for informed consent was waived.

From January 2005 to December 2016, 22667 consecutive US-guided 14-gauge CNBs for breast lesions from 211986 breast US procedures were performed at our institution. We retrospectively reviewed the biopsy results to analyze the annual trends in US-guided CNB. Proven malignancies assessed as BI-RADS category 6 lesions ( $n$ $=282)$, male patients $(n=62)$, and lesions with nondiagnostic pathologic results (e.g., adipose tissue only or cell paucity) $(n=26)$ were excluded from this study. Finally, a total of 22297 breast masses of 17241 patients (mean age, $45.7 \pm 11.6$ years; range, 11 to 92 years) were included in this study.

\section{Biopsy Procedure}

US-guided 14-gauge CNB was performed using the free- hand technique and a high-resolution US unit with 5-15MHz linear transducers (HDI 5000 or 3000 or iU22, Philips' Advanced Technology Laboratories, Bothell, WA, USA; or LOGIQ 9 or LOGIQ E9, GE Healthcare, Milwaukee, WI, USA). Each procedure was performed with the patient in the supine position under local anesthesia. A 14-gauge automated core biopsy needle with a spring-loaded biopsy gun (Promac 2.2 L, Manan Medical Products, Northbrook, IL, USA), a 14-gauge Tru-Cut needle with a 22-mm throw (SACN biopsy needle; Medical Device Technologies, Gainesville, FL, USA), or a 14-gauge dual-action semiautomatic core biopsy needle with a 22-mm throw (Stericut with a coaxial needle, TSK Laboratory, Tochigi, Japan) was used. All biopsies were performed by one of 42 radiologists with less than 2 years of experience who was in fellowship training, or by one of six radiologists with 2 or more years of clinical experience who was a specialist in breast imaging and biopsies. At least four or five core samples per lesion were routinely obtained.

\section{Data Analysis}

The radiological and pathologic findings of US-guided 14-gauge CNB were obtained from medical records. Breast lesions were classified based on the lesion size, BI-RADS category on US, and pathologic results of CNB. Each variable was categorized as follows: lesion size as $\leq 10 \mathrm{~mm}$, $>10$ to $\leq 20 \mathrm{~mm},>20$ to $\leq 30 \mathrm{~mm},>30$ to $\leq 40 \mathrm{~mm}$, or $>40$ $\mathrm{mm}$; BI-RADS category on US (category 1 to 5); pathologic results of CNB as benign (neither malignant nor high-risk), high-risk (e.g., atypia, including atypical ductal hyperplasia, lobular neoplasia, radial sclerosing lesions, and possible phyllodes tumors), or malignant (e.g., ductal carcinoma in situ [DCIS] and invasive cancer). The malignancy rates for DCIS and invasive cancer were calculated as proportions

Table 1. Distribution of US-Guided 14-Gauge Core-Needle Biopsy and Total US, 2005-2016

\begin{tabular}{|c|c|c|c|c|c|c|c|c|c|c|c|c|c|c|c|}
\hline & 2005 & 2006 & 2007 & 2008 & 2009 & 2010 & 2011 & 2012 & 2013 & 2014 & 2015 & 2016 & Total & $\begin{array}{c}\text { OR } \\
(95 \% \mathrm{CI})\end{array}$ & $P$ \\
\hline $\begin{array}{l}\text { No. of total } \\
\text { breast US } \\
\text { examinations }\end{array}$ & 7808 & 10635 & 11963 & 13766 & 17171 & 17859 & 19151 & 20808 & 21854 & 22377 & 22698 & 25896 & 211986 & $\begin{array}{c}1.091 \\
(1.089 \\
1.093)\end{array}$ & $<0.001$ \\
\hline $\begin{array}{l}\text { No. of US-guided } \\
\text { core-needle } \\
\text { biopsies }\end{array}$ & 1294 & 1504 & 1377 & 1639 & 1975 & 2080 & 1938 & 2019 & 1972 & 2111 & 2334 & 2054 & 22297 & $\begin{array}{c}1.043 \\
(1.039 \\
1.047)\end{array}$ & $<0.001$ \\
\hline $\begin{array}{l}\text { Percentage } \\
(\%)^{*}\end{array}$ & 16.6 & 14.1 & 11.5 & 12.3 & 11.5 & 11.7 & 10.1 & 9.7 & 9.0 & 9.4 & 10.3 & 7.9 & & $\begin{array}{r}0.952 \\
(0.948 \\
0.956)\end{array}$ & $<0.001$ \\
\hline
\end{tabular}

*Percentage of total core-needle biopsies performed among total USs. CI = confidence interval, OR = odds ratio, US = ultrasonography 
among all biopsied breast masses of DCIS and invasive cancer, respectively, diagnosed using US-guided 14-gauge CNB. The total malignancy rate was calculated as the total proportion of both DCIS and invasive cancer among all biopsied cases.

To assess overall trends over time in CNB based on the lesion size, BI-RADS category, and pathologic results, the Mantel-Haenszel chi-square test and Poisson regression analysis were performed. The Cochran-Armitage test was performed for trends in the malignancy rate and the Cochran-Mantel-Haenszel test was performed to adjust variables. A generalized linear model with an identity link for normal distribution was used to calculate the odds ratio (OR) for associations between the calendar year and each variable. $O R$ was interpreted as the number of times each indicator increased each year. Analyses were performed with a computerized statistic program (SAS, version 9.4, Cary, NC, USA or SPSS, version 23.0, IBM Corp., Armonk,

Table 2. Distribution of US-Guided 14-Gauge Core-Needle Biopsy According to Lesion Size and BI-RADS Category

\begin{tabular}{|c|c|c|c|c|c|c|c|c|c|c|c|c|c|c|c|}
\hline & 2005 & 2006 & 2007 & 2008 & 2009 & 2010 & 2011 & 2012 & 2013 & 2014 & 2015 & 2016 & Total & $\begin{array}{c}\text { OR } \\
(95 \% \mathrm{CI})\end{array}$ & $P$ \\
\hline \multicolumn{16}{|l|}{ Size $(\mathrm{mm})$} \\
\hline$\leq 10$ & $\begin{array}{c}575 \\
(44.4)\end{array}$ & $\begin{array}{c}698 \\
(46.4)\end{array}$ & $\begin{array}{c}682 \\
(49.5)\end{array}$ & $\begin{array}{c}959 \\
(58.5)\end{array}$ & $\begin{array}{c}989 \\
(50.1)\end{array}$ & $\begin{array}{c}1043 \\
(50.1)\end{array}$ & $\begin{array}{c}997 \\
(51.4)\end{array}$ & $\begin{array}{c}1057 \\
(52.4)\end{array}$ & $\begin{array}{c}1000 \\
(50.7)\end{array}$ & $\begin{array}{c}979 \\
(46.4)\end{array}$ & $\begin{array}{l}1125 \\
(48.2)\end{array}$ & $\begin{array}{c}828 \\
(40.3)\end{array}$ & $\begin{array}{l}10932 \\
(49.0)\end{array}$ & $\begin{array}{l}1.036 \\
(1.03 \\
1.041)\end{array}$ & $<0.001$ \\
\hline $\begin{array}{c}>10 \text { to } \\
\leq 20\end{array}$ & $\begin{array}{c}466 \\
(36.0)\end{array}$ & $\begin{array}{c}502 \\
(33.4)\end{array}$ & $\begin{array}{c}452 \\
(32.8)\end{array}$ & $\begin{array}{c}451 \\
(27.5)\end{array}$ & $\begin{array}{c}688 \\
(34.8)\end{array}$ & $\begin{array}{c}699 \\
(33.6)\end{array}$ & $\begin{array}{c}614 \\
(31.7)\end{array}$ & $\begin{array}{c}638 \\
(31.6)\end{array}$ & $\begin{array}{c}654 \\
(33.2)\end{array}$ & $\begin{array}{c}715 \\
(33.9)\end{array}$ & $\begin{array}{c}779 \\
(33.4)\end{array}$ & $\begin{array}{c}734 \\
(35.7)\end{array}$ & $\begin{array}{c}7392 \\
(33.2)\end{array}$ & $\begin{array}{l}1.047 \\
(1.04 \\
1.054)\end{array}$ & $<0.001$ \\
\hline $\begin{array}{c}>20 \text { to } \\
\leq 30\end{array}$ & $\begin{array}{c}159 \\
(12.3)\end{array}$ & $\begin{array}{c}196 \\
(13.0)\end{array}$ & $\begin{array}{c}150 \\
(10.9)\end{array}$ & $\begin{array}{l}129 \\
(7.9)\end{array}$ & $\begin{array}{c}196 \\
(9.9)\end{array}$ & $\begin{array}{c}203 \\
(9.8)\end{array}$ & $\begin{array}{c}203 \\
(10.5)\end{array}$ & $\begin{array}{c}194 \\
(9.6)\end{array}$ & $\begin{array}{c}188 \\
(9.5)\end{array}$ & $\begin{array}{c}254 \\
(12.0)\end{array}$ & $\begin{array}{c}252 \\
(10.8)\end{array}$ & $\begin{array}{c}285 \\
(13.9)\end{array}$ & $\begin{array}{c}2409 \\
(10.8)\end{array}$ & $\begin{array}{l}1.052 \\
(1.04 \\
1.065)\end{array}$ & $<0.001$ \\
\hline $\begin{array}{c}>30 \text { to } \\
\leq 40\end{array}$ & $\begin{array}{c}44 \\
(3.4)\end{array}$ & $\begin{array}{c}63 \\
(4.2)\end{array}$ & $\begin{array}{c}64 \\
(4.7)\end{array}$ & $\begin{array}{c}63 \\
(3.8)\end{array}$ & $\begin{array}{c}69 \\
(3.5)\end{array}$ & $\begin{array}{c}64 \\
(3.1)\end{array}$ & $\begin{array}{c}70 \\
(3.6)\end{array}$ & $\begin{array}{c}69 \\
(3.4)\end{array}$ & $\begin{array}{c}61 \\
(3.1)\end{array}$ & $\begin{array}{c}89 \\
(4.2)\end{array}$ & $\begin{array}{c}80 \\
(3.4)\end{array}$ & $\begin{array}{c}98 \\
(4.8)\end{array}$ & $\begin{array}{c}834 \\
(3.7)\end{array}$ & $\begin{array}{c}1.048 \\
(1.027 \\
1.068)\end{array}$ & $<0.001$ \\
\hline$>40$ & $\begin{array}{c}50 \\
(3.9)\end{array}$ & $\begin{array}{c}45 \\
(3.0)\end{array}$ & $\begin{array}{c}29 \\
(2.1)\end{array}$ & $\begin{array}{c}37 \\
(2.3)\end{array}$ & $\begin{array}{c}33 \\
(1.7)\end{array}$ & $\begin{array}{c}71 \\
(3.4)\end{array}$ & $\begin{array}{c}54 \\
(2.8)\end{array}$ & $\begin{array}{c}61 \\
(3.0)\end{array}$ & $\begin{array}{c}69 \\
(3.5)\end{array}$ & $\begin{array}{c}74 \\
(3.5)\end{array}$ & $\begin{array}{c}98 \\
(4.2)\end{array}$ & $\begin{array}{c}109 \\
(5.3)\end{array}$ & $\begin{array}{c}730 \\
(3.3)\end{array}$ & $\begin{array}{c}1.103 \\
(1.079 \\
1.127)\end{array}$ & $<0.001$ \\
\hline \multicolumn{16}{|c|}{ BI-RADS category } \\
\hline 1 or 2 & $\begin{array}{c}6 \\
(0.5)\end{array}$ & $\begin{array}{c}17 \\
(1.1)\end{array}$ & $\begin{array}{c}10 \\
(0.7)\end{array}$ & $\begin{array}{c}9 \\
(0.6)\end{array}$ & $\begin{array}{c}8 \\
(0.4)\end{array}$ & $\begin{array}{c}11 \\
(0.5)\end{array}$ & $\begin{array}{c}21 \\
(1.1)\end{array}$ & $\begin{array}{c}15 \\
(0.7)\end{array}$ & $\begin{array}{c}9 \\
(0.5)\end{array}$ & $\begin{array}{c}5 \\
(0.2)\end{array}$ & $\begin{array}{c}4 \\
(0.2)\end{array}$ & $\begin{array}{c}4 \\
(0.2)\end{array}$ & $\begin{array}{c}119 \\
(0.5)\end{array}$ & $\begin{array}{c}0.951 \\
(0.902 \\
1.002)\end{array}$ & 0.058 \\
\hline 3 & $\begin{array}{c}346 \\
(26.7)\end{array}$ & $\begin{array}{c}310 \\
(20.6)\end{array}$ & $\begin{array}{c}285 \\
(20.7)\end{array}$ & $\begin{array}{c}237 \\
(14.5)\end{array}$ & $\begin{array}{c}338 \\
(17.1)\end{array}$ & $\begin{array}{c}360 \\
(17.3)\end{array}$ & $\begin{array}{c}401 \\
(20.7)\end{array}$ & $\begin{array}{c}347 \\
(17.2)\end{array}$ & $\begin{array}{c}318 \\
(16.1)\end{array}$ & $\begin{array}{c}306 \\
(14.5)\end{array}$ & $\begin{array}{c}264 \\
(11.3)\end{array}$ & $\begin{array}{c}156 \\
(7.6)\end{array}$ & $\begin{array}{c}3668 \\
(16.5)\end{array}$ & $\begin{array}{c}0.979 \\
(0.970 \\
0.988)\end{array}$ & $<0.001$ \\
\hline $4 a$ & $\begin{array}{c}608 \\
(47.0)\end{array}$ & $\begin{array}{c}725 \\
(48.2)\end{array}$ & $\begin{array}{c}711 \\
(51.6)\end{array}$ & $\begin{array}{c}1004 \\
(61.3)\end{array}$ & $\begin{array}{c}1211 \\
(61.3)\end{array}$ & $\begin{array}{c}1254 \\
(60.3)\end{array}$ & $\begin{array}{c}1100 \\
(56.8)\end{array}$ & $\begin{array}{c}1229 \\
(60.9)\end{array}$ & $\begin{array}{c}1238 \\
(62.8)\end{array}$ & $\begin{array}{c}1274 \\
(60.4)\end{array}$ & $\begin{array}{c}1472 \\
(63.1)\end{array}$ & $\begin{array}{c}1222 \\
(59.5)\end{array}$ & $\begin{array}{l}13048 \\
(58.5)\end{array}$ & $\begin{array}{c}1.062 \\
(1.056 \\
1.067)\end{array}$ & $<0.001$ \\
\hline $4 b$ & $\begin{array}{c}42 \\
(3.3)\end{array}$ & $\begin{array}{c}78 \\
(5.2)\end{array}$ & $\begin{array}{c}90 \\
(6.5)\end{array}$ & $\begin{array}{c}100 \\
(6.1)\end{array}$ & $\begin{array}{c}117 \\
(5.9)\end{array}$ & $\begin{array}{c}124 \\
(6.0)\end{array}$ & $\begin{array}{c}72 \\
(3.7)\end{array}$ & $\begin{array}{c}79 \\
(3.9)\end{array}$ & $\begin{array}{c}84 \\
(4.3)\end{array}$ & $\begin{array}{c}116 \\
(5.5)\end{array}$ & $\begin{array}{c}141 \\
(6.0)\end{array}$ & $\begin{array}{l}160 \\
(7.8)\end{array}$ & $\begin{array}{l}1203 \\
(5.4)\end{array}$ & $\begin{array}{c}1.065 \\
(1.048 \\
1.083)\end{array}$ & $<0.001$ \\
\hline $4 C$ & $\begin{array}{c}113 \\
(8.7)\end{array}$ & $\begin{array}{c}130 \\
(8.6)\end{array}$ & $\begin{array}{c}102 \\
(7.4)\end{array}$ & $\begin{array}{c}93 \\
(5.7)\end{array}$ & $\begin{array}{c}102 \\
(5.2)\end{array}$ & $\begin{array}{c}130 \\
(6.3)\end{array}$ & $\begin{array}{c}117 \\
(6.0)\end{array}$ & $\begin{array}{c}99 \\
(4.9)\end{array}$ & $\begin{array}{c}97 \\
(4.9)\end{array}$ & $\begin{array}{c}132 \\
(6.3)\end{array}$ & $\begin{array}{c}182 \\
(7.8)\end{array}$ & $\begin{array}{c}223 \\
(10.9)\end{array}$ & $\begin{array}{l}1520 \\
(6.8)\end{array}$ & $\begin{array}{c}1.054 \\
(1.038 \\
1.069)\end{array}$ & $<0.001$ \\
\hline 5 & $\begin{array}{c}179 \\
(13.8)\end{array}$ & $\begin{array}{c}244 \\
(16.2)\end{array}$ & $\begin{array}{c}179 \\
(13.0)\end{array}$ & $\begin{array}{c}196 \\
(12.0)\end{array}$ & $\begin{array}{c}199 \\
(10.1)\end{array}$ & $\begin{array}{c}201 \\
(9.7)\end{array}$ & $\begin{array}{c}227 \\
(11.7)\end{array}$ & $\begin{array}{c}250 \\
(12.4)\end{array}$ & $\begin{array}{c}226 \\
(11.5)\end{array}$ & $\begin{array}{c}278 \\
(13.2)\end{array}$ & $\begin{array}{c}271 \\
(11.6)\end{array}$ & $\begin{array}{c}289 \\
(14.1)\end{array}$ & $\begin{array}{c}2739 \\
(12.3)\end{array}$ & $\begin{array}{c}1.039 \\
(1.028 \\
1.050)\end{array}$ & $<0.001$ \\
\hline
\end{tabular}

Values are presented as numbers of core-needle biopsies with percentages in parenthesis. OR is defined as how many times number of biopsies increased each year. BI-RADS = Breast Imaging-Reporting and Data System 
NY, USA), and a $p$ value of less than 0.05 was considered statistically significant.

\section{RESULTS}

Time Trends in CNB Based on the Lesion Size, BI-RADS Category, and Pathology

Both the total number of US scans and US-guided CNBs increased significantly during the study period while the proportion of US-guided CNBs to the total number of US scans decreased 0.952 times per year $(0 R=0.952$ per year, $95 \%$ confidence interval [CI]: 0.948, 0.956, $p$ $<0.001$ ) (Table 1). Table 2 shows distributions of USguided 14-gauge CNB based on the lesion size and BIRADS category. Table 3 shows the distribution of US-guided 14-gauge CNB based on the pathologic results. Figure 1 illustrates distributions US-guided 14-gauge CNB based on the lesion size, BI-RADS category, and pathologic results. With the Poisson regression analysis, we found statistically significant trends in all variables ( $p<0.001$, respectively), except for BI-RADS categories 1 and 2. BI-RADS category 3 lesions showed a statistically significant decreasing trend of 0.979 times per year ( $95 \%$ CI: $0.970,0.988 ; p<0.001$ ). The number of BI-RADS category 1 or 2 lesions also decreased to 0.951 times per year without statistical significance (95\% CI: 0.902, 1.002; $p=0.058$ ), and the rest of the variables showed an increasing trend over time. Among all biopsied cases, the proportion of high-risk and DCIS lesions increased while the proportion of benign lesions decreased over time (Fig. 2).

Unadjusted and Adjusted Time Trends in the Malignancy Rate

For the malignancy rate, the unadjusted results showed significantly increasing trends in rates of total malignancy $(p<0.001)$, DCIS $(p<0.001)$, and invasive cancer ( $p$ $=0.039)$. After adjusting for the BI-RADS category, the increasing trends in rates of total malignancy $(p<0.001)$ and DCIS $(p<0.003)$ remained significant, but the rate of invasive cancer did not show a statistically significant increasing trend $(p=0.215)$. Figure 3 shows the time trend line (by linear regression) in the rate of total malignancy based on the BI-RADS category. The increasing trends in the malignancy rate were statistically significant in BIRADS categories $4 a(p<0.001), 4 b(p=0.001)$, and $4 c$ $(p=0.046)$ for DCIS, BI-RADS category $4 \mathrm{~b}(p=0.024)$ for invasive cancer, and BI-RADS categories $4 \mathrm{a}(p=0.020), 4 \mathrm{~b}$ $(p<0.001)$, and $4 c(p=0.002)$ for total malignancy (Table 4$)$.

\section{DISCUSSION}

Our results show that in a large series $(n=22297)$ of US-guided CNBs for breast lesions, the overall number of both US scans and US-guided CNBs increased from 2005 to 2016. The increase in the total number of US scans performed may partly contribute to the increase in the

Table 3. Distribution of US-Guided 14-Gauge Core-Needle Biopsy According to Pathologic Results

\begin{tabular}{|c|c|c|c|c|c|c|c|c|c|c|c|c|c|c|c|}
\hline $\begin{array}{c}\text { Pathologic } \\
\text { Results }\end{array}$ & 2005 & 2006 & 2007 & 2008 & 2009 & 2010 & 2011 & 2012 & 2013 & 2014 & 2015 & 2016 & Total & $\begin{array}{c}\text { OR } \\
(95 \% \mathrm{CI})\end{array}$ & $P$ \\
\hline Benign & $\begin{array}{c}941 \\
(72.7)\end{array}$ & $\begin{array}{c}1063 \\
(70.7)\end{array}$ & $\begin{array}{l}1013 \\
(73.6)\end{array}$ & $\begin{array}{l}1250 \\
(76.3)\end{array}$ & $\begin{array}{c}1513 \\
(76.6)\end{array}$ & $\begin{array}{c}1575 \\
(75.7)\end{array}$ & $\begin{array}{l}1468 \\
(75.8)\end{array}$ & $\begin{array}{l}1497 \\
(74.2)\end{array}$ & $\begin{array}{l}1467 \\
(74.4)\end{array}$ & $\begin{array}{l}1469 \\
(69.6)\end{array}$ & $\begin{array}{l}1619 \\
(69.4)\end{array}$ & $\begin{array}{l}1320 \\
(64.3)\end{array}$ & $\begin{array}{l}16195 \\
(72.6)\end{array}$ & $\begin{array}{c}1.035 \\
(1.032 \\
1.038)\end{array}$ & $<0.001$ \\
\hline High risk & $\begin{array}{c}37 \\
(2.9)\end{array}$ & $\begin{array}{c}30 \\
(2.0)\end{array}$ & $\begin{array}{c}26 \\
(1.9)\end{array}$ & $\begin{array}{c}45 \\
(2.8)\end{array}$ & $\begin{array}{c}74 \\
(3.8)\end{array}$ & $\begin{array}{c}64 \\
(3.1)\end{array}$ & $\begin{array}{c}52 \\
(2.7)\end{array}$ & $\begin{array}{c}57 \\
(2.8)\end{array}$ & $\begin{array}{c}81 \\
(4.1)\end{array}$ & $\begin{array}{c}111 \\
(5.3)\end{array}$ & $\begin{array}{c}111 \\
(4.8)\end{array}$ & $\begin{array}{c}108 \\
(5.3)\end{array}$ & $\begin{array}{l}796 \\
(3.6)\end{array}$ & $\begin{array}{c}1.129 \\
(1.112 \\
1.146)\end{array}$ & $<0.001$ \\
\hline $\begin{array}{l}\text { Total } \\
\text { malignancy }\end{array}$ & $\begin{array}{c}316 \\
(24.4)\end{array}$ & $\begin{array}{c}411 \\
(27.3)\end{array}$ & $\begin{array}{c}338 \\
(24.6)\end{array}$ & $\begin{array}{c}344 \\
(21.0)\end{array}$ & $\begin{array}{c}388 \\
(19.7)\end{array}$ & $\begin{array}{c}441 \\
(21.2)\end{array}$ & $\begin{array}{c}418 \\
(21.6)\end{array}$ & $\begin{array}{c}465 \\
(23.0)\end{array}$ & $\begin{array}{c}424 \\
(21.5)\end{array}$ & $\begin{array}{c}531 \\
(25.2)\end{array}$ & $\begin{array}{c}604 \\
(25.9)\end{array}$ & $\begin{array}{c}626 \\
(30.5)\end{array}$ & $\begin{array}{c}5306 \\
(23.8)\end{array}$ & $\begin{array}{l}1.058 \\
(1.05 \\
1.067)\end{array}$ & $<0.001$ \\
\hline DCIS & $\begin{array}{c}35 \\
(2.7)\end{array}$ & $\begin{array}{c}44 \\
(2.9)\end{array}$ & $\begin{array}{c}33 \\
(2.4)\end{array}$ & $\begin{array}{c}47 \\
(2.9)\end{array}$ & $\begin{array}{c}49 \\
(2.5)\end{array}$ & $\begin{array}{c}62 \\
(3.0)\end{array}$ & $\begin{array}{c}57 \\
(2.9)\end{array}$ & $\begin{array}{c}62 \\
(3.1)\end{array}$ & $\begin{array}{c}69 \\
(3.5)\end{array}$ & $\begin{array}{c}94 \\
(4.5)\end{array}$ & $\begin{array}{c}101 \\
(4.3)\end{array}$ & $\begin{array}{c}98 \\
(4.8)\end{array}$ & $\begin{array}{l}751 \\
(3.4)\end{array}$ & $\begin{array}{l}1.107 \\
(1.09, \\
1.124)\end{array}$ & $<0.001$ \\
\hline $\begin{array}{c}\text { Invasive } \\
\text { cancer }\end{array}$ & $\begin{array}{c}281 \\
(21.7)\end{array}$ & $\begin{array}{c}367 \\
(24.4)\end{array}$ & $\begin{array}{c}305 \\
(22.2)\end{array}$ & $\begin{array}{c}297 \\
(18.1)\end{array}$ & $\begin{array}{c}339 \\
(17.2)\end{array}$ & $\begin{array}{c}379 \\
(18.2)\end{array}$ & $\begin{array}{c}361 \\
(18.6)\end{array}$ & $\begin{array}{c}403 \\
(20.0)\end{array}$ & $\begin{array}{c}355 \\
(18.0)\end{array}$ & $\begin{array}{c}437 \\
(20.7)\end{array}$ & $\begin{array}{c}503 \\
(21.6)\end{array}$ & $\begin{array}{c}528 \\
(25.7)\end{array}$ & $\begin{array}{c}4555 \\
(20.4)\end{array}$ & $\begin{array}{c}1.051 \\
(1.044 \\
1.057)\end{array}$ & $<0.001$ \\
\hline
\end{tabular}

Values are presented as numbers of core-needle biopsies with percentages in parenthesis. $0 \mathrm{R}$ is defined as how many times number of biopsies increased each year. DCIS = ductal carcinoma in situ 

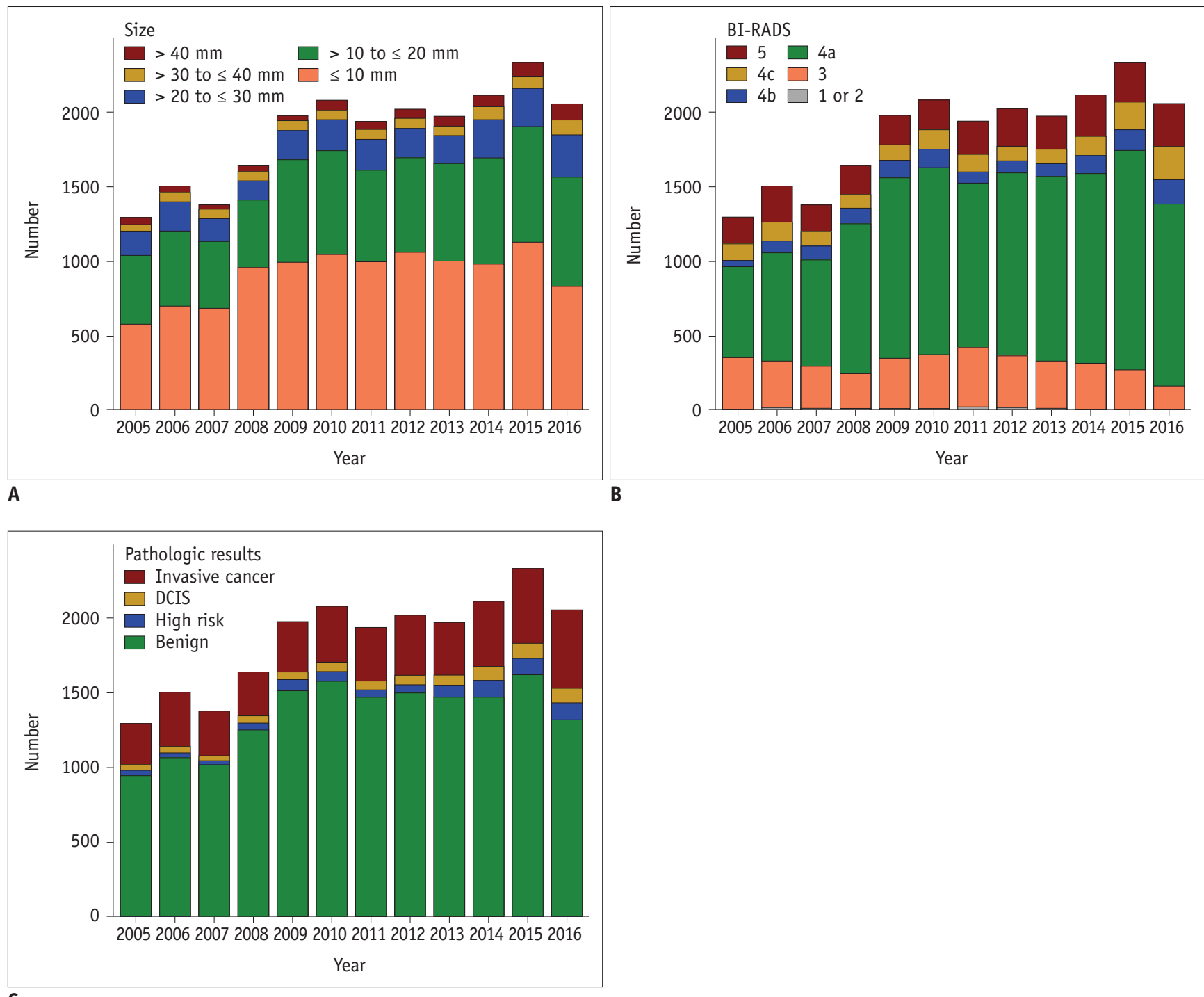

C

Fig. 1. Distribution of US-guided 14-gauge core-needle biopsies based on lesion size (A), BI-RADS category (B), and pathologic results (C) from 2005 to 2016. BI-RADS = Breast Imaging-Reporting and Data System, DCIS = ductal carcinoma in situ, US = ultrasonography

number of biopsies; however, the proportion of US-guided CNBs among the total number of US scans decreased over time. One possible reason for this proportional decrease is revisions made to BI-RADS during the study period. The 5th edition of BI-RADS released in 2013 had several changes in the US section to include newer technology, such as elastography, and some additional descriptors in its lexicon $(11,12)$. There were several studies in which additional sonoelastography led to downgrading of BI-RADS 4a masses, potentially reducing the number of unnecessary biopsies (13-15). In our study, the decreasing rate of biopsies over time might be partly attributed to efforts made to reduce the number of unnecessary biopsies with various novel techniques, such as elastography.
Our analysis revealed that only BI-RADS category 3 lesions decreased significantly over time in terms of both the total number and percentage $(26.7 \%$ in 2005 to $7.6 \%$ in 2016) among the total biopsied lesions. The total malignancy rate among BI-RADS category 3 lesions remained at approximately $1 \%$ throughout the study period. This observation is encouraging as otherwise there might have been more unnecessary patient cost and anxiety caused by biopsy because of the high rate of benign lesions in the biopsy results for BI-RADS category 3 lesions. One possible explanation for this may be the efforts to downgrade BIRADS category 3 lesions by radiologists at our institution. Since March 2010, we have trained our radiologists to downgrade certain lesions found using supplemental 

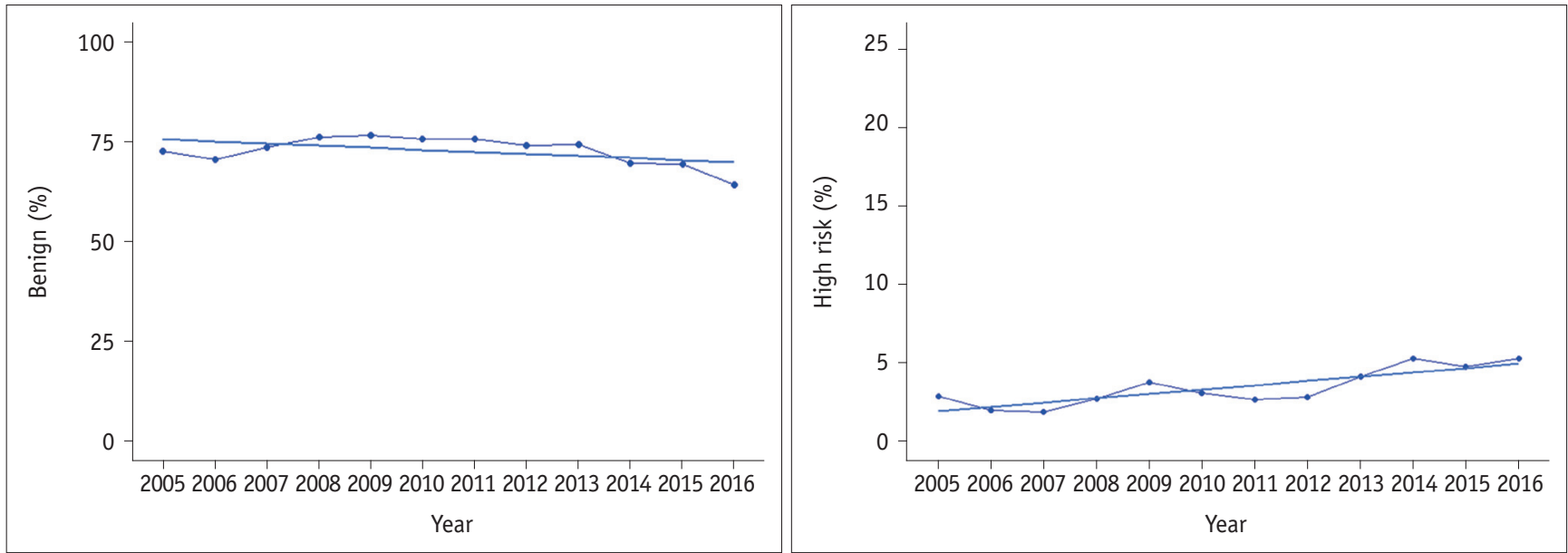

A
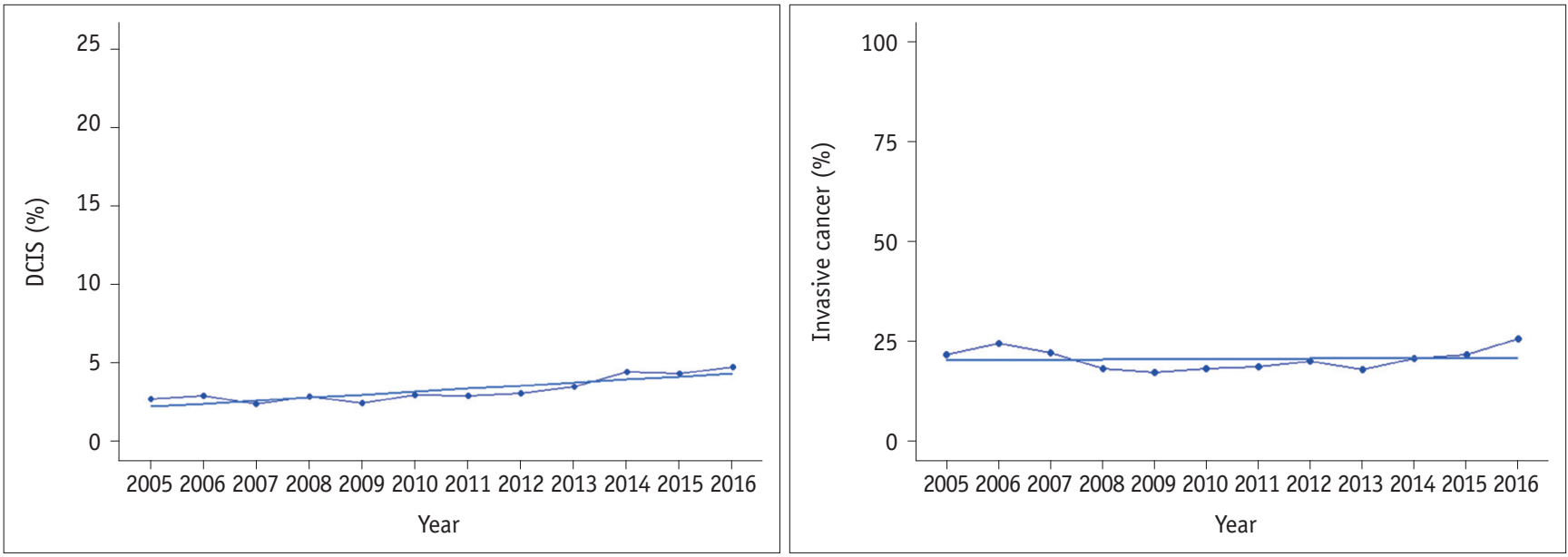

C

D

Fig. 2. Line plot and trend lines for proportion of pathologic results.

Linear lines (estimated by linear regression) show significant decrease in proportion of benign (A) lesions and significant increase in proportions of high-risk (B) and DCIS (C) lesions over time but no significant trend in proportion of invasive cancer (D) lesions.

screening US to BI-RADS category 2 in efforts to reduce the false-positive rate (16). In a previous study, the downgrade criteria reduced the BI-RADS category 3 rate from 28.3\% to $12.6 \%$ without loss of cancer detection, and the biopsy rate also decreased significantly over 3 years. Despite using different inclusion criteria in the two studies, our results showed that the decrease in the BI-RADS category 3 rate was most prominent and persistent from 2011 to 2016, which fit the timeframe in which the downgrade criteria were first incorporated into the clinical practice at our institution.

The total malignancy rate in the results of US-guided CNB slightly increased over time with statistical significance, and this trend persisted after adjusting for the BI-RADS category. These results were consistent with our initial assumption that the malignancy rate in the results of
CNB should be constant or increase in order to ensure that unnecessary biopsies were not performed. Among cases of total malignancy, the rate of DCIS showed an increasing trend during our study period. This observation can be attributed to the widespread use of screening mammography, which reveals clinically occult pre-invasive disease, and advances of other diagnostic imaging modalities, such as US and magnetic resonance imaging (17-19). In addition, improved resolution and technique have enabled visualization of microcalcifications on US, thus increasing the detection rate of DCIS using US-guided biopsy, which was formerly diagnosed using stereotacticguided biopsy (20-22).

When lesions were classified based on the BI-RADS category, the total malignancy rates of BI-RADS category $4 a, 4 b$, and $4 c$ lesions showed slightly increasing trends 


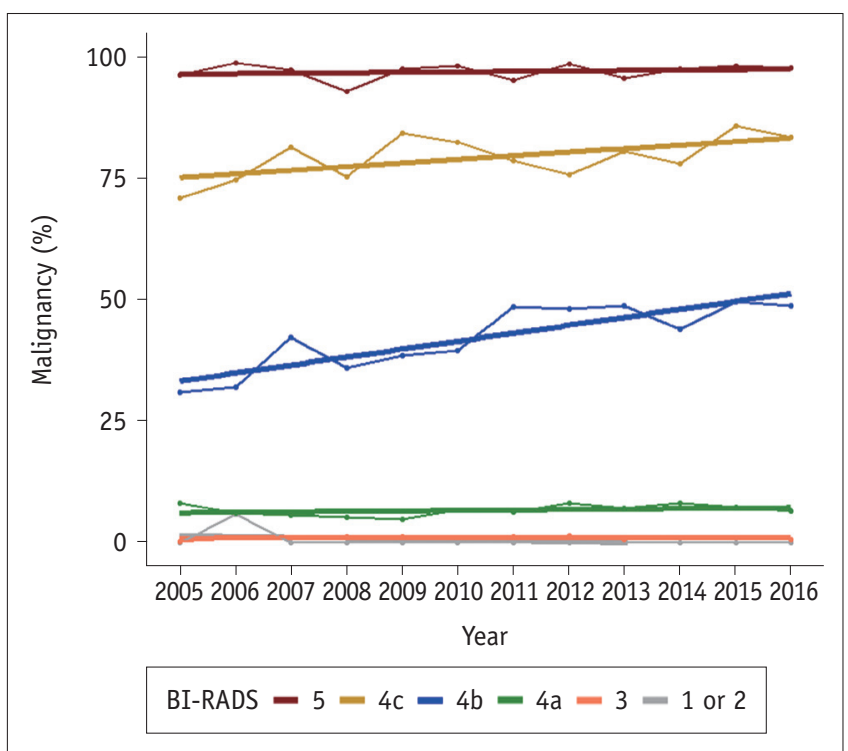

Fig. 3. Line plot and trend line for total malignancy rate based on BI-RADS category. Linear lines (estimated by linear regression) show that total malignancy rates increased significantly over time in BI-RADS categories $4 \mathrm{a}(p=0.020), 4 \mathrm{~b}(p<0.001)$, and $4 \mathrm{C}(p=$ $0.002)$ but not in BI-RADS category $3(p=0.324)$ or $5(p=0.175)$.

over time. Because BI-RADS category 4 on US indicates a lesion suspected with malignancy for which biopsy is recommended, the aforementioned result may correlate with decreased false-positive results in the US findings of breast lesions. Our results showed that the malignancy rate based on the BI-RADS category generally matched the stratification of positive predictive values for each BI-RADS category during the past 12 years, with an exception in year 2008 (92.9\% in BI-RADS 5). BI-RADS suggests a positive predictive value of less than $2 \%, 3-10 \%, 11-50 \%$, more than $95 \%$ for categories $3,4 a, 4 b, 4 c$, and 5 , respectively (11).

In 2005, a community population-based trend study was performed on the frequency and malignancy rate of breast biopsies, similar to our study (23). However, many subjects of this past study underwent surgical biopsies, which are no longer recommended as the initial diagnostic approach (24). In addition, unlike our study, there was no BI-RADS classification for US lesions, which is now used in clinical practice. Thus, our study better reflects the latest clinical management approaches chosen for breast lesions compared with the previous study. Another recent study described time trends in minimally invasive breast biopsy for 9 years (25); however, this study primarily analyzed geographic/ ethnic variations in breast biopsy and did not assess malignancy rates relating to unnecessary biopsies and cost- ineffectiveness in the clinical practice, while our study focused on the malignancy rate of breast biopsies.

Our study has a few limitations. First, this study was retrospectively conducted at a single tertiary hospital; therefore, its results cannot be generalized immediately to other populations. Further multicenter studies are required before our results can be applied to general clinical circumstances. Second, there was no standard diagnostic reference, such as surgical excision or follow-up data, to confirm the pathologic results of CNB. However, US-guided 14-gauge CNB is a reliable diagnostic modality that allows accurate assessments $(4,6,7)$. A previous study at our institution showed reliable sensitivity (95.4\%) and no false-positive results for US-guided CNB from 2005 to 2012 (8). Third, we did not classify US-guided CNB based on the indication of biopsy (e.g., screening or diagnostic clinical setting), which would potentially affect trends.

In conclusion, we found an overall slightly increasing trend in the malignancy rate in the results of US-guided 14-gauge CNB for breast lesions and an increase in the total number of biopsies performed from 2005 to 2016. This trend persisted after adjusting for the BI-RADS category. We could also observe the efforts made to avoid unnecessary biopsies during the 12-year study period with a large population at a single institution.

\section{Conflicts of Interest}

All authors have no conflict of interest including financial or consultant, institutional and other relationship in this study.

\section{Acknowledgments}

We acknowledge all the study members for their help.

\section{ORCID iDs}

Inha Jung

https://orcid.org/0000-0001-5999-1281

Kyunghwa Han

https://orcid.org/0000-0002-5687-7237

Min Jung Kim

https://orcid.org/0000-0003-4949-1237

Hee Jung Moon

https://orcid.org/0000-0002-5643-5885

Jung Hyun Yoon

https://orcid.org/0000-0002-2100-3513

Vivian Youngjean Park

https://orcid.org/0000-0002-5135-4058 
Table 4. Malignancy Rate According to BI-RADS Category

\begin{tabular}{|c|c|c|c|c|c|c|c|c|c|c|c|c|c|c|}
\hline Year & 2005 & 2006 & 2007 & 2008 & 2009 & 2010 & 2011 & 2012 & 2013 & 2014 & 2015 & 2016 & Total & $P$ \\
\hline \multicolumn{15}{|l|}{ BI-RADS 3} \\
\hline DCIS & $\begin{array}{c}1 \\
(0.3)\end{array}$ & $\begin{array}{c}0 \\
(0)\end{array}$ & $\begin{array}{c}1 \\
(0.4)\end{array}$ & $\begin{array}{c}2 \\
(0.8)\end{array}$ & $\begin{array}{c}1 \\
(0.3)\end{array}$ & $\begin{array}{c}1 \\
(0.3)\end{array}$ & $\begin{array}{c}1 \\
(0.3)\end{array}$ & $\begin{array}{c}2 \\
(0.6)\end{array}$ & $\begin{array}{c}0 \\
(0)\end{array}$ & $\begin{array}{c}2 \\
(0.7)\end{array}$ & $\begin{array}{c}2 \\
(0.8)\end{array}$ & $\begin{array}{c}0 \\
(0)\end{array}$ & $\begin{array}{c}13 \\
(0.4)\end{array}$ & 0.280 \\
\hline $\begin{array}{c}\text { Invasive } \\
\text { cancer }\end{array}$ & $\begin{array}{c}0 \\
(0)\end{array}$ & $\begin{array}{c}3 \\
(1.0)\end{array}$ & $\begin{array}{c}2 \\
(0.7)\end{array}$ & $\begin{array}{c}1 \\
(0.4)\end{array}$ & $\begin{array}{c}3 \\
(0.9)\end{array}$ & $\begin{array}{c}3 \\
(0.8)\end{array}$ & $\begin{array}{c}4 \\
(1.0)\end{array}$ & $\begin{array}{c}3 \\
(0.9)\end{array}$ & $\begin{array}{c}2 \\
(0.6)\end{array}$ & $\begin{array}{c}1 \\
(0.3)\end{array}$ & $\begin{array}{c}1 \\
(0.4)\end{array}$ & $\begin{array}{c}1 \\
(0.6)\end{array}$ & $\begin{array}{c}24 \\
(0.7)\end{array}$ & 0.446 \\
\hline $\begin{array}{l}\text { Total } \\
\text { malignancy }\end{array}$ & $\begin{array}{c}1 \\
(0.3)\end{array}$ & $\begin{array}{c}3 \\
(1.0)\end{array}$ & $\begin{array}{c}3 \\
(1.1)\end{array}$ & $\begin{array}{c}3 \\
(1.3)\end{array}$ & $\begin{array}{c}4 \\
(1.2)\end{array}$ & $\begin{array}{c}4 \\
(1.1)\end{array}$ & $\begin{array}{c}5 \\
(1.3)\end{array}$ & $\begin{array}{c}5 \\
(1.4)\end{array}$ & $\begin{array}{c}2 \\
(0.6)\end{array}$ & $\begin{array}{c}3 \\
(1.0)\end{array}$ & $\begin{array}{c}3 \\
(1.1)\end{array}$ & $\begin{array}{c}1 \\
(0.6)\end{array}$ & $\begin{array}{c}37 \\
(1.0)\end{array}$ & 0.324 \\
\hline \multicolumn{15}{|l|}{ BI-RADS 4a } \\
\hline DCIS & $\begin{array}{c}16 \\
(2.6)\end{array}$ & $\begin{array}{c}13 \\
(1.8)\end{array}$ & $\begin{array}{c}8 \\
(1.1)\end{array}$ & $\begin{array}{c}10 \\
(1.0)\end{array}$ & $\begin{array}{c}13 \\
(1.1)\end{array}$ & $\begin{array}{c}21 \\
(1.7)\end{array}$ & $\begin{array}{c}12 \\
(1.1)\end{array}$ & $\begin{array}{c}24 \\
(2.0)\end{array}$ & $\begin{array}{c}28 \\
(2.3)\end{array}$ & $\begin{array}{c}40 \\
(3.1)\end{array}$ & $\begin{array}{c}35 \\
(2.4)\end{array}$ & $\begin{array}{c}37 \\
(3.0)\end{array}$ & $\begin{array}{c}257 \\
(2.0)\end{array}$ & 0.001 \\
\hline $\begin{array}{c}\text { Invasive } \\
\text { cancer }\end{array}$ & $\begin{array}{c}34 \\
(5.6)\end{array}$ & $\begin{array}{c}31 \\
(4.3)\end{array}$ & $\begin{array}{c}32 \\
(4.5)\end{array}$ & $\begin{array}{c}43 \\
(4.3)\end{array}$ & $\begin{array}{c}46 \\
(3.8)\end{array}$ & $\begin{array}{c}63 \\
(5.0)\end{array}$ & $\begin{array}{c}58 \\
(5.3)\end{array}$ & $\begin{array}{c}77 \\
(6.3)\end{array}$ & $\begin{array}{c}59 \\
(4.8)\end{array}$ & $\begin{array}{c}63 \\
(5.0)\end{array}$ & $\begin{array}{c}74 \\
(5.0)\end{array}$ & $\begin{array}{c}42 \\
(3.4)\end{array}$ & $\begin{array}{c}622 \\
(4.8)\end{array}$ & 0.446 \\
\hline $\begin{array}{l}\text { Total } \\
\text { malignancy }\end{array}$ & $\begin{array}{c}50 \\
(8.2)\end{array}$ & $\begin{array}{c}44 \\
(6.1)\end{array}$ & $\begin{array}{c}40 \\
(5.6)\end{array}$ & $\begin{array}{c}53 \\
(5.3)\end{array}$ & $\begin{array}{c}59 \\
(4.9)\end{array}$ & $\begin{array}{c}84 \\
(6.7)\end{array}$ & $\begin{array}{c}70 \\
(6.4)\end{array}$ & $\begin{array}{c}101 \\
(8.2)\end{array}$ & $\begin{array}{c}87 \\
(7.0)\end{array}$ & $\begin{array}{c}103 \\
(8.1)\end{array}$ & $\begin{array}{c}109 \\
(7.4)\end{array}$ & $\begin{array}{c}79 \\
(6.5)\end{array}$ & $\begin{array}{c}879 \\
(6.7)\end{array}$ & 0.020 \\
\hline \multicolumn{15}{|l|}{ BI-RADS 4b } \\
\hline DCIS & $\begin{array}{c}3 \\
(7.1)\end{array}$ & $\begin{array}{c}1 \\
(1.3)\end{array}$ & $\begin{array}{c}5 \\
(5.6)\end{array}$ & $\begin{array}{c}6 \\
(6.0)\end{array}$ & $\begin{array}{c}8 \\
(6.8)\end{array}$ & $\begin{array}{c}12 \\
(9.7)\end{array}$ & $\begin{array}{c}8 \\
(11.1)\end{array}$ & $\begin{array}{c}6 \\
(7.6)\end{array}$ & $\begin{array}{c}5 \\
(6.0)\end{array}$ & $\begin{array}{c}12 \\
(10.3)\end{array}$ & $\begin{array}{c}17 \\
(12.1)\end{array}$ & $\begin{array}{c}19 \\
(11.9)\end{array}$ & $\begin{array}{c}102 \\
(8.5)\end{array}$ & 0.001 \\
\hline $\begin{array}{c}\text { Invasive } \\
\text { cancer }\end{array}$ & $\begin{array}{c}10 \\
(23.8)\end{array}$ & $\begin{array}{c}24 \\
(30.8)\end{array}$ & $\begin{array}{c}33 \\
(36.7)\end{array}$ & $\begin{array}{c}30 \\
(30.0)\end{array}$ & $\begin{array}{c}37 \\
(31.6)\end{array}$ & $\begin{array}{c}37 \\
(29.8)\end{array}$ & $\begin{array}{c}27 \\
(37.5)\end{array}$ & $\begin{array}{c}32 \\
(40.5)\end{array}$ & $\begin{array}{c}36 \\
(42.9)\end{array}$ & $\begin{array}{c}39 \\
(33.6)\end{array}$ & $\begin{array}{c}53 \\
(37.6)\end{array}$ & $\begin{array}{c}59 \\
(36.9)\end{array}$ & $\begin{array}{c}417 \\
(34.7)\end{array}$ & 0.024 \\
\hline $\begin{array}{l}\text { Total } \\
\text { malignancy }\end{array}$ & $\begin{array}{c}13 \\
(31.0)\end{array}$ & $\begin{array}{c}25 \\
(32.1)\end{array}$ & $\begin{array}{c}38 \\
(42.2)\end{array}$ & $\begin{array}{c}36 \\
(36.0)\end{array}$ & $\begin{array}{c}45 \\
(38.5)\end{array}$ & $\begin{array}{c}49 \\
(39.5)\end{array}$ & $\begin{array}{c}35 \\
(48.6)\end{array}$ & $\begin{array}{c}38 \\
(48.1)\end{array}$ & $\begin{array}{c}41 \\
(48.8)\end{array}$ & $\begin{array}{c}51 \\
(44.0)\end{array}$ & $\begin{array}{c}70 \\
(49.7)\end{array}$ & $\begin{array}{c}78 \\
(48.8)\end{array}$ & $\begin{array}{c}519 \\
(43.1)\end{array}$ & 0.001 \\
\hline \multicolumn{15}{|l|}{ BI-RADS 4C } \\
\hline DCIS & $\begin{array}{c}4 \\
(3.5)\end{array}$ & $\begin{array}{c}15 \\
(11.5)\end{array}$ & $\begin{array}{c}12 \\
(11.8)\end{array}$ & $\begin{array}{c}11 \\
(11.8)\end{array}$ & $\begin{array}{c}8 \\
(7.8)\end{array}$ & $\begin{array}{c}14 \\
(10.8)\end{array}$ & $\begin{array}{c}14 \\
(12.0)\end{array}$ & $\begin{array}{c}12 \\
(12.1)\end{array}$ & $\begin{array}{c}11 \\
(11.3)\end{array}$ & $\begin{array}{c}22 \\
(16.7)\end{array}$ & $\begin{array}{c}24 \\
(13.2)\end{array}$ & $\begin{array}{c}22 \\
(9.9)\end{array}$ & $\begin{array}{c}169 \\
(11.1)\end{array}$ & 0.046 \\
\hline $\begin{array}{c}\text { Invasive } \\
\text { cancer }\end{array}$ & $\begin{array}{c}76 \\
(67.3)\end{array}$ & $\begin{array}{c}82 \\
(63.1)\end{array}$ & $\begin{array}{c}71 \\
(69.6)\end{array}$ & $\begin{array}{c}59 \\
(63.4)\end{array}$ & $\begin{array}{c}78 \\
(76.5)\end{array}$ & $\begin{array}{c}93 \\
(71.5)\end{array}$ & $\begin{array}{c}78 \\
(66.7)\end{array}$ & $\begin{array}{c}63 \\
(63.6)\end{array}$ & $\begin{array}{c}67 \\
(69.1)\end{array}$ & $\begin{array}{c}81 \\
(61.4)\end{array}$ & $\begin{array}{c}132 \\
(72.5)\end{array}$ & $\begin{array}{c}164 \\
(73.5)\end{array}$ & $\begin{array}{c}1044 \\
(68.7)\end{array}$ & 0.193 \\
\hline $\begin{array}{l}\text { Total } \\
\text { malignancy }\end{array}$ & $\begin{array}{c}80 \\
(70.8)\end{array}$ & $\begin{array}{c}97 \\
(74.6)\end{array}$ & $\begin{array}{c}83 \\
(81.4)\end{array}$ & $\begin{array}{c}70 \\
(75.3)\end{array}$ & $\begin{array}{c}86 \\
(84.3)\end{array}$ & $\begin{array}{c}107 \\
(82.3)\end{array}$ & $\begin{array}{c}92 \\
(78.6)\end{array}$ & $\begin{array}{c}75 \\
(75.8)\end{array}$ & $\begin{array}{c}78 \\
(80.4)\end{array}$ & $\begin{array}{c}103 \\
(78.0)\end{array}$ & $\begin{array}{c}156 \\
(85.7)\end{array}$ & $\begin{array}{c}186 \\
(83.4)\end{array}$ & $\begin{array}{c}1213 \\
(79.8)\end{array}$ & 0.002 \\
\hline \multicolumn{15}{|l|}{ BI-RADS 5} \\
\hline DCIS & $\begin{array}{c}11 \\
(6.2)\end{array}$ & $\begin{array}{c}15 \\
(6.2)\end{array}$ & $\begin{array}{c}7 \\
(3.9)\end{array}$ & $\begin{array}{c}18 \\
(9.2)\end{array}$ & $\begin{array}{c}19 \\
(9.6)\end{array}$ & $\begin{array}{c}14 \\
(7.0)\end{array}$ & $\begin{array}{c}22 \\
(9.7)\end{array}$ & $\begin{array}{c}18 \\
(7.2)\end{array}$ & $\begin{array}{c}25 \\
(11.1)\end{array}$ & $\begin{array}{c}18 \\
(6.5)\end{array}$ & $\begin{array}{c}23 \\
(8.5)\end{array}$ & $\begin{array}{c}20 \\
(6.9)\end{array}$ & $\begin{array}{c}210 \\
(7.7)\end{array}$ & 0.156 \\
\hline $\begin{array}{c}\text { Invasive } \\
\text { cancer }\end{array}$ & $\begin{array}{c}161 \\
(89.9)\end{array}$ & $\begin{array}{c}226 \\
(92.6)\end{array}$ & $\begin{array}{c}167 \\
(93.3)\end{array}$ & $\begin{array}{c}164 \\
(83.7)\end{array}$ & $\begin{array}{c}175 \\
(87.9)\end{array}$ & $\begin{array}{c}183 \\
(91.0)\end{array}$ & $\begin{array}{c}194 \\
(85.5)\end{array}$ & $\begin{array}{c}228 \\
(91.2)\end{array}$ & $\begin{array}{c}191 \\
(84.5)\end{array}$ & $\begin{array}{c}253 \\
(91.0)\end{array}$ & $\begin{array}{c}243 \\
(89.7)\end{array}$ & $\begin{array}{c}262 \\
(90.7)\end{array}$ & $\begin{array}{l}2447 \\
(89.3)\end{array}$ & 0.361 \\
\hline $\begin{array}{l}\text { Total } \\
\text { malignancy }\end{array}$ & $\begin{array}{c}172 \\
(96.1)\end{array}$ & $\begin{array}{c}241 \\
(98.8)\end{array}$ & $\begin{array}{c}174 \\
(97.2)\end{array}$ & $\begin{array}{c}182 \\
(92.9)\end{array}$ & $\begin{array}{c}194 \\
(97.5)\end{array}$ & $\begin{array}{c}197 \\
(98.0)\end{array}$ & $\begin{array}{c}216 \\
(95.6)\end{array}$ & $\begin{array}{c}246 \\
(98.4)\end{array}$ & $\begin{array}{c}216 \\
(95.6)\end{array}$ & $\begin{array}{c}271 \\
(97.5)\end{array}$ & $\begin{array}{c}266 \\
(98.2)\end{array}$ & $\begin{array}{c}282 \\
(97.6)\end{array}$ & $\begin{array}{c}2657 \\
(97.0)\end{array}$ & 0.175 \\
\hline
\end{tabular}

Values are presented as numbers of malignant results with percentages in parenthesis. There was one case of breast cancer being assigned BI-RADS category 1 or 2 during 12-year study period.

Eun-Kyung Kim

https://orcid.org/0000-0002-3368-5013

\section{REFERENCES}

1. Fuhrman GM, Cederbom GJ, Bolton JS, King TA, Duncan $\mathrm{JL}$, Champaign $\mathrm{JL}$, et al. Image-guided core-needle breast biopsy is an accurate technique to evaluate patients with nonpalpable imaging abnormalities. Ann Surg 1998;227:932939
2. Liberman L. Clinical management issues in percutaneous core breast biopsy. Radiol Clin North Am 2000;38:791-807

3. Dillon MF, Hill AD, Quinn CM, O'Doherty A, McDermott EW, O'Higgins N. The accuracy of ultrasound, stereotactic, and clinical core biopsies in the diagnosis of breast cancer, with an analysis of false-negative cases. Ann Surg 2005;242:701707

4. Bassett LW, Mahoney MC, Apple SK. Interventional breast imaging: current procedures and assessing for concordance with pathology. Radiol Clin North Am 2007;45:881-894

5. Youk JH, Kim EK, Kim MJ, Oh KK. Sonographically guided 
14-gauge core needle biopsy of breast masses: a review of 2,420 cases with long-term follow-up. AJR Am J Roentgenol 2008;190:202-207

6. Liberman L, Feng TL, Dershaw DD, Morris EA, Abramson AF. US-guided core breast biopsy: use and cost-effectiveness. Radiology 1998;208:717-723

7. Philpotts LE, Hooley RJ, Lee CH. Comparison of automated versus vacuum-assisted biopsy methods for sonographically guided core biopsy of the breast. AJR Am J Roentgenol 2003;180:347-351

8. Jung I, Kim MJ, Moon HJ, Yoon JH, Kim EK. Ultrasonographyguided 14-gauge core biopsy of the breast: results of 7 years of experience. Ultrasonography 2018;37:55-62.

9. Silverstein MJ, Recht A, Lagios MD, Bleiweiss IJ, Blumencranz PW, Gizienski T, et al. Special report: consensus conference III. Image-detected breast cancer: state-of-the-art diagnosis and treatment. J Am Coll Surg 2009;209:504-520

10. Lakoma A, Kim ES. Minimally invasive surgical management of benign breast lesions. Gland Surg 2014;3:142-148

11. D'Orsi CJ, Sickles EA, Mendelson EB, Morris EA. 2013 ACR BIRADS Atlas, Breast Imaging Reporting and Data System. 5th ed. Reston, VA: American College of Radiology, 2013.

12. Spak DA, Plaxco JS, Santiago L, Dryden MJ, Dogan BE. BIRADS ${ }^{\circledR}$ fifth edition: a summary of changes. Diagn Interv Imaging 2017;98:179-190

13. Lee SH, Chang JM, Kim WH, Bae MS, Seo M, Koo HR, et al. Added value of shear-wave elastography for evaluation of breast masses detected with screening US imaging. Radiology 2014;273:61-69

14. Kim MY, Cho N, Yi A, Koo HR, Yun BL, Moon WK. Sonoelastography in distinguishing benign from malignant complex breast mass and making the decision to biopsy. Korean J Radiol 2013;14:559-567

15. Zheng X, Huang Y, Wang Y, Liu Y, Li F, Han J, et al. Combination of different types of elastography in downgrading ultrasound Breast Imaging-Reporting and Data System category 4 a breast lesions. Breast Cancer Res Treat
2019;174:423-432

16. Kim SY, Kim MJ, Moon HJ, Yoon JH, Kim EK. Application of the downgrade criteria to supplemental screening ultrasound for women with negative mammography but dense breasts. Medicine (Baltimore) 2016;95:e5279

17. DeSantis CE, Ma J, Goding Sauer A, Newman LA, Jemal A. Breast cancer statistics, 2017, racial disparity in mortality by state. CA Cancer J Clin 2017;67:439-448

18. Trentin C, Dominelli V, Maisonneuve P, Menna S, Bazolli B, Luini A, et al. Predictors of invasive breast cancer and lymph node involvement in ductal carcinoma in situ initially diagnosed by vacuum-assisted breast biopsy: experience of 733 cases. Breast 2012;21:635-640

19. Jansen SA. Ductal carcinoma in situ: detection, diagnosis, and characterization with magnetic resonance imaging. Semin Ultrasound CT MR 2011;32:306-318

20. Bae S, Yoon JH, Moon HJ, Kim MJ, Kim EK. Breast microcalcifications: diagnostic outcomes according to imageguided biopsy method. Korean J Radiol 2015;16:996-1005

21. Soo MS, Baker JA, Rosen EL, Vo TT. Sonographically guided biopsy of suspicious microcalcifications of the breast: a pilot study. AJR Am J Roentgenol 2002;178:1007-1015

22. Yi J, Lee EH, Kwak JJ, Cha JG, Jung SH. Retrieval rate and accuracy of ultrasound-guided 14-G semi-automated core needle biopsy of breast microcalcifications. Korean J Radiol 2014;15:12-19

23. Ghosh K, Melton LJ III, Suman VJ, Grant CS, Sterioff S, Brandt KR, et al. Breast biopsy utilization: a population-based study. Arch Intern Med 2005;165:1593-1598

24. American College of Surgeons. National Accrediation Program for Breast Centers standards manual. Chicago, IL: American College of Surgeons, 2018

25. Zimmermann CJ, Sheffield KM, Duncan CB, Han Y, Cooksley $\mathrm{CD}$, Townsend $\mathrm{CM} \mathrm{Jr}$, et al. Time trends and geographic variation in use of minimally invasive breast biopsy. J Am Coll Surg 2013;216:814-824 